\title{
Pengembangan Sistem Penjualan Menggunakan UML Dan Proses Bisnis E-Commerce Pada TB. Purnama Banjarnegara
}

\author{
Memi Dwi Kartika ${ }^{1}$, Yudi Priyadi ${ }^{2}$ \\ ${ }^{1,2}$ Universitas Telkom; Jl. Telekomunikasi, Bandung 40257, Telp/Fax (022) 7566456 \\ ${ }^{1}$ Prodi Manajemen Bisnis Telekomunikasi dan Informatika, Universitas Telkom, Bandung \\ ${ }^{2}$ Prodi Rekayasa Perangkat Lunak, Universitas Telkom, Bandung \\ e-mail: ${ }^{1}$ memi.dwi@gmail.com, ${ }^{2}$ whyphi@telkomuniversity.ac.id
}

\begin{abstract}
Abstrak
E-commerce merupakan hasil teknologi informasi dan komunikasi yang membantu perusahaan dan konsumen untuk saling bertukar informasi. Namun demikian, masih banyak perusahaan di Indonesia yang belum menggunakan e-commerce dalam kegiatan bisnisnya, salah satunya yaitu TB.Purnama. Perusahaan ini memiliki kelemahan pada model bisnis yang sedang terjadi, yaitu: proses penjualan dilakukan secara konvensional, promosi melalui wordof-mouth, manajemen stok barang kurang diperhatikan, dan jangkuan pemasaran yang terbatas. Penelitian ini bertujuan untuk membuat rancangan perbaikan model bisnis berdasarkan hasil analisis SWOT, membuat prototype penjualan bahan bangunan, yang dirancang menggunakan pemodelan UML. Pemodelan ini menghasilkan Use Case Diagram yang memiliki rangkaian dengan jumlah yang sama dan konsisten sebanyak 12 diagram pada Use Case Scenario, Activity Diagram, dan Sequence Diagram, antara lain yaitu: Konfirmasi Pembayaran, Verifikasi Pembayaran, dan Rekap Data Penjualan. Selain itu, UML ini juga menghasilkan Class Diagram bernama Sistem E-Commerce TB.Purnama yang terdiri dari 7 Class, diantaranya yaitu: Konsumen, Produk, dan Pembayaran. Hasil uji validitas dan reliabilitas pengambangan system ini, menggunakan perhitungan Gwet's AC1, dengan nilai sebesar 0,75125 yang masuk pada jenis proporsi kesepakatan "Substansial". Proporsi kesepakatan menunjukan bahwa, rekomendasi perbaikan model bisnis serta prototype user interface website sudah baik, sehingga model bisnis rekomendasi dapat diterapkan pada kegiatan bisnisnya.
\end{abstract}

Kata kunci-Pengembangan Sistem, E-Commerce, SWOT, UML, Gwet's AC1

\begin{abstract}
E-commerce is the result of information and communication technology that helps companies and consumers exchange information. However, there are still many companies in Indonesia that have not used e-commerce in their business activities, one of which is TB.Purnama. This company has weaknesses in the current business model, namely: the sales process is carried out conventionally, promotion through word-of-mouth, lack of attention to stock management, and limited marketing reach. This study aims to make a business model improvement plan based on the SWOT analysis results to create a building material sales prototype, which is designed using UML modeling. This modeling produces a Use Case Diagram with a series of the same number. It is consistent with 12 diagrams in Use Case Scenarios, Activity Diagrams, and Sequence Diagrams, including Payment Confirmation, Payment Verification, and Sales Data Recap. Besides, this UML also produces a Class Diagram called TB. Purnama E-Commerce System which consists of 7 classes, including Consumers, Products, and Payments. The validity and reliability test results of this floating system use Gwet's AC1 calculation, with a value of 0.75125 , which is included in the type of
\end{abstract}


agreement proportion "substantial." The proportion of the agreement shows that the recommendations for improving the business model and the prototype for the website user interface are good so that the recommended business model can be applied to its business activities.

\section{Keywords - System Development, E-Commerce, SWOT, UML, Gwet's AC1}

\section{PENDAHULUAN}

$F$ -commerce merupakan transaksi digital yang dilakukan oleh individu maupaun organisasi yang menggunakan internet, web, maupun aplikasi yang berjalan pada perangkat seluler [1]. Selain itu, untuk proses bisnis dari e-commerce sudah memiliki proses yang baku, sehingga dapat diadopsi dan disesuaikan dengan sistem yang terjadi [2]. Perdagangan secara elektronik dapat mendukung perusahaan dalam menyediakan layanan dan komoditas, informasi bisnis, tetap menjaga ikatan antara pemasok, pelanggan, dan vendor, serta dapat mengelola transaksi bisnis dengan lebih baik [3]. Manfaat lain dengan adanya e-commerce, juga dijelaskan dalam penelitian lain yang menyimpulkan bahwa e-commerce dapat membantu perusahaan dalam menjual produk dengan jangkauan yang lebih besar dan juga dapat memperluas pasar, serta melakukan penyimpanan data dan pencetakan laporan yang dapat diakses dan disimpan dalam web [4], [5].

Dalam artikel yang ditulis oleh Ernawati [6], menyampaikan bahwa percepatan pembangunan infrastruktur nasional yang diprogramkan oleh pemerintah dapat mendorong perkembangan bisnis bahan bangunan di Indonesia, hal ini ditandai dengan meningkatnya nilai transaksi ekspor bahan bangunan sebesar 10,72\% atau sekitar USD378 juta dibandingkan tahun 2016, seperti yang dikatakan oleh Dirjen Pengembangan Ekspor Nasional Kementrian Perdagangan, Arlinda. Selain itu juga, Deputi Infrastruktur Bekraf Sungkari [7] mengatakan sebagian besar e-commerce di Indonesia lebih banyak yang terjun ke market place jenis barang konsumen, daripada membuka pasar yang lebih unik seperti startup bahan bangunan dan alat berat yang sudah mulai dikembangkan oleh negara lain. Hal tersebut dapat menjadi sebuah peluang yang menjanjikan bagi pelaku bisnis bahan bangunan di Indonesia.

TB. Purnama merupakan salah satu produsen yang bergerak di bidang penjualan material bahan bangunan yang berlokasi di Banjarnegara, Jawa Tengah. Dalam proses penjualannya, TB. Purnama masih menggunakan sistem penjualan konvensional, dimana konsumen harus mendatangi toko secara langsung untuk melakukan pembelian, dan mengetahui informasi ketersediaan produk. Sampai saat ini, cara penjualan konvensional masih dapat berjalan dengan cukup baik. Namun demikian, masih banyak kendala-kendala yang dihadapi, diantaranya yaitu: manajemen stok barang yang kurang diperhatikan, keterbatasan proses pendataan laporan, jenis promosi yang masih hanya menggunakan media word-of-mouth, serta keterbatasan penjualan dan pendistribusian bahan bangunan dalam skala besar. Dari semua kendala yang sudah terungkap tersebut, selanjutnya dapat dirangkum menjadi satu masalah yang fokus mengenai bagaimana menganalisis dan merancang perangkat lunak untuk mengatasi kendala-kendala tersebut melalui pengembangan sistem penjualan. Salah satu caranya, yaitu dengan melakukan rekayasa dan mengkombinasikan pemodelan sistem dan proses bisnisnya.

Berdasarkan latar belakang di atas, maka diusulkan suatu solusi untuk merancang sebuah sistem penjualan e-commerce, berbasis website. Untuk merancang sistem informasi penjualan TB. Purnama, maka pemodelan Unified Modeling Language (UML) yang berorientasi objek, dipilih sebagai metode sebagai alat untuk analisis awal kegiatan ini. Pemilihan UML, sebagai pemodelan untuk merancang dan mengembangkan sistem informasi dinilai memiliki kelebihan

Kartika, et al,. [Pengembangan Sistem Penjualan Menggunakan UML dan Proses Bisnis E-Commerce pada 
tersendiri, yaitu UML lebih fleksibel, mudah dipahami, dan lebih mudah dalam perluasan dan uji sistem [8], [9]. Aman dan Rajeev [10] dalam penelitiannya, juga mengungkapkan bahwa UML, sangat berguna dalam merencanakan kebutuhan sistem, mendokumentasikan struktur, mengidentifikasi objek dan menjelaskan hubungan antar objek dalam sistem. Selain itu, UML juga tidak bergantung dengan bahasa pemrograman manapun [11], [12].

Tujuan artikel ini adalah menganalisis dan merancang sebuah sistem informasi penjualan yang dapat membantu TB. Purnama dalam meningkatkan performa penjualan serta pelayanan agar lebih efektif dan efisien. Hal ini sejalan dengan penelitian dari Himawan [13], yang menyatakan bahwa adanya website e-commerce dapat memudahkan pemilik toko untuk memberikan pelayanan yang optimal dengan memberikan informasi 24 jam serta dapat diakses dimana saja dan kapan saja. Selain itu, e-commerce dapat memberikan kemudahan bagi konsumen untuk membeli produk yang diinginkan tanpa harus mendatangi toko tersebut [14].

\section{METODE PENELITIAN}

Metode pada penelitian ini, terbagi ke dalam beberapa tahap. Metode penelitian yang digunakan, mengacu pada pendekatan System Development Life Cycle (SDLC). Tahapan atau fase yang digunakan pada penelitian ini, berfokus pada tahap identifikasi masalah, menentukan kebutuhan informasi, analisis kebutuhan sistem, dan merancang rekomendasi sistem. Lihat Gambar 1.

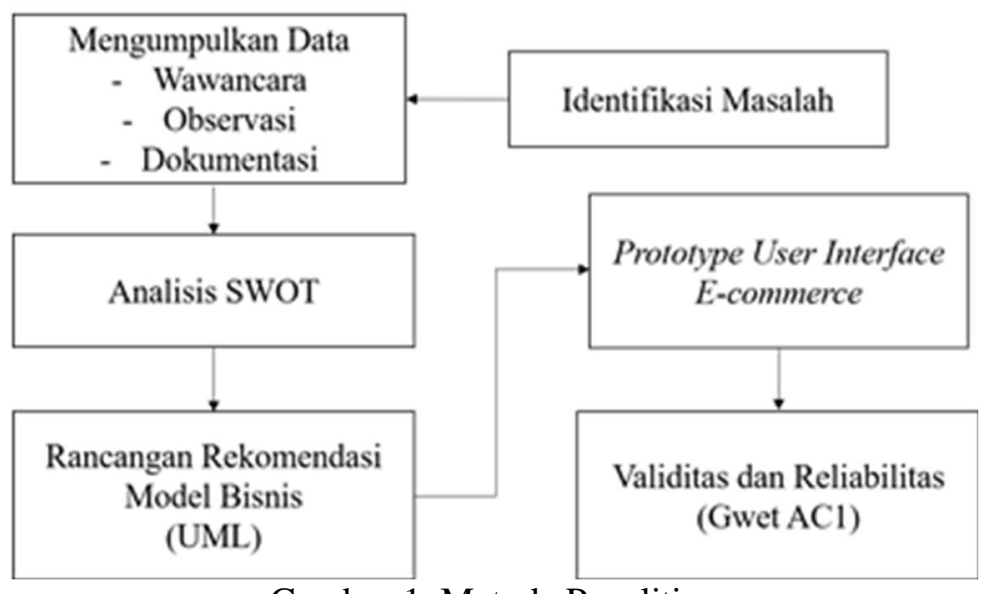

Gambar 1. Metode Penelitian

Langkah pertama yang dilakukan dalam penelitian ini, yaitu: mengindentifikasi masalah, kemudian dilanjutkan dengan mengumpulkan berbagai data dan informasi yang dibutuhkan. Data dan informasi tersebut akan digunakan sebagai bahan untuk melakukan analisis Strength, Weakness, Opportunity, and Threat (SWOT) saat mengidentifikasi kekurangan yang ada pada sistem berjalan. Setelah melakukan analisis SWOT, tahap selanjutnya yang dilakukan, yaitu membuat rekomendasi rancangan sistem baru untuk model bisnis menggunakan pemodelan UML. Langkah berikutnya, yaitu membuat prototype user interface untuk halaman web $e$ commerce. Sebagai tahap terakhir yang dilakukan, adalah melakukan validitas dan reliabilitas terhadap rancangan model bisnis dan prototype user interface yang telah dibuat. Alat yang digunakan untuk melakukan uji validitas dan reliatibilitas adalah statistika perhitungan Gwet's AC1.

\footnotetext{
Kartika, et al,. [Pengembangan Sistem Penjualan Menggunakan UML dan Proses Bisnis E-Commerce pada
} TB. Purnama Banjarnegara] 


\subsection{System Development Life Cycle (SDLC)}

SDLC merupakan metode yang digunakan untuk mengembangkan suatu sistem yang dibagi menjadi tahap-tahap formal yang diselesaikan secara berurutan [15]. Kenneth dan Julie dalam bukunya [16], menyampaikan bahwa terdapat tujuh fase atau tahap yang harus diperhatikan dalam membangun suatu sistem informasi menggunakan SDLC. Berikut ini adalah tahapannya [11], yaitu: Tahap pertama, terdiri dari identifikasi masalah, peluang, dan tujuan. Tahap kedua, menentukan kebutuhan informasi. Tahap ketiga, menganalisis kebutuhan sistem. Tahap keempat, merancang sistem rekomendasi. Tahap kelima, mengembangkan dan mendokumentasikan software. Tahap keenam, menguji dan memelihara sistem. Tahap ketujuh, mengimplementasikan serta mengevaluasi sistem.

\section{2 Gwet's ACl}

Gwet's AC1 merupakan perhitungan statistika yang digunakan untuk mengukur hasil indeks kesepakatan antara dua pengamat atau pakar dalam pengujian suatu model rekomendasi [17]. Hasil pertanyaan pengamat disajikan dalam Tabel 1, yang nantinya akan digunakan untuk menghitung nilai $\mathrm{AC} 1$.

Tabel 1. Hasil Pertanyaan Pengamat

\begin{tabular}{|c|c|c|c|}
\hline \multirow{2}{*}{ Pengamat 1 } & \multicolumn{3}{|c|}{ Pengamat 2 } \\
\cline { 2 - 4 } & Ya & Tidak & Total \\
\hline Ya & $\mathrm{A}$ & $\mathrm{B}$ & $\mathrm{B} 1=\mathrm{A}+\mathrm{B}$ \\
\hline Tidak & $\mathrm{C}$ & $\mathrm{D}$ & $\mathrm{B} 2=\mathrm{C}+\mathrm{D}$ \\
\hline Total & $\mathrm{A} 1=\mathrm{A}+\mathrm{C}$ & $\mathrm{A} 2=\mathrm{B}+\mathrm{D}$ & $\mathrm{N}$ \\
\hline
\end{tabular}

Berikut ini adalah beberapa langkah yang dilakukan untuk melakukan perhitungan Gwet's AC1. Langkah pertama yang dilakukan, yaitu menghitung kesepakatan yang terobservasi $(\mathrm{P})$ yang disajikan pada persamaan 1.

$$
\mathrm{P}=\frac{\mathrm{A}+\mathrm{D}}{\mathrm{N}}
$$

Langkah selanjutnya, yaitu menghitung probabilitas chance-agreement atau $\mathrm{e}(\mathrm{\gamma})$ pada persamaan 2 berikut ini.

$$
e(\mathrm{\gamma})=2 P_{1}\left(1-P_{1}\right)
$$

Dimana $\quad \mathrm{P}_{1}=\frac{(\mathrm{A} 1+\mathrm{B} 1) / 2}{\mathrm{~N}}$ merepresentasikan perkiraan kemungkinan pengamat mengelompokkan data ke dalam kategori "Ya". A1 dan B1 masing-masing adalah jumlah pengamat 1 atau 2 mengelompokkan data ke dalam kategori "Ya", sedanglan $\mathrm{N}$ adalah jumlah data. Untuk menghitung statistika $\mathrm{AC} 1$ dapat menggunakan persamaan (3) berikut ini.

$$
A C 1=\frac{P-e(\mathrm{\gamma})}{1-e(\mathrm{\gamma})}
$$

Berikut ini, merupakan interpretasi nilai dari Gwet's AC1 untuk mengukur indeks kesepakatan antar dua pengamat atau ahli [18].

Tabel 2. Interprestasi Nilai Gwet's AC1

\begin{tabular}{|l|l|}
\hline \multicolumn{1}{|c|}{ Index Kappa } & \multicolumn{1}{c|}{ Proporsi Kesepakatan } \\
\hline$<0$ & Rendah (less than chance agreement) \\
\hline $0.01-0.20$ & Sedikit (slight agreement) \\
\hline $0.21-0.40$ & Cukup (fair agreement) \\
\hline $0.41-0.60$ & Sedang (moderate agreement) \\
\hline $0.61-0.80$ & Substansial (substansial agreement) \\
\hline $0.81-1$ & Hampir sempurna (almost perfect) \\
\hline
\end{tabular}

Kartika, et al,. [Pengembangan Sistem Penjualan Menggunakan UML dan Proses Bisnis E-Commerce pada TB. Purnama Banjarnegara] 


\section{HASIL DAN PEMBAHASAN}

Berikut ini, merupakan data hasil analisis dan pembahasan yang telah dilakukan pada TB.Purnama Banjarnegara. Data diperoleh dari proses wawancara, observasi dan dokumentasi secara langsung di lapangan. Daftar wawancara diajukan kepada narasumber yang berperan sebagai pemilik dari TB. Purnama, dapat dicermati pada Tabel 3.

Tabel 3. Daftar Pertanyaan dan Jawaban Wawancara

\begin{tabular}{|c|c|}
\hline No. & Daftar Pertanyaan dan Jawaban \\
\hline 1 & $\begin{array}{l}\text { Bagaimana model bisnis yang ada di TB. Purnama? } \\
\text { Jawaban: "Model bisnis yang ada di TB. Purnama sementara masih menggunakan } \\
\text { model bisnis manual seperti toko-toko biasa, ya seperti orang datang ke toko, } \\
\text { memesan barang, dibikinkan nota secara manual, setelah itu membayar uang yang } \\
\text { harus dibayarkan sesuai dengan harga barang, setelah itu barang dikirim ke } \\
\text { pelanggan, seperti itu". }\end{array}$ \\
\hline 2 & $\begin{array}{l}\text { Jumlah karyawan di TB. Purnama ada berapa dan bagaimana pembagian tugasnya? } \\
\text { Jawaban: "Untuk karyawan sendiri sementara ada } 7 \text { orang, untuk pembagian } \\
\text { tugasnya itu sendiri untuk } 1 \text { orang pembantu di toko (pelayan), } 3 \text { orang sebagai sopir, } \\
\text { dan } 3 \text { orang sebagai karyawan bongkar muat dan ikut melayani di toko". }\end{array}$ \\
\hline 3 & $\begin{array}{l}\text { Bagaimana cara TB. Purnama menarik konsumen? } \\
\text { Jawaban: "Caranya yaitu dengan membuat harga itu bisa bersaing kompetitif dengan } \\
\text { toko-toko lain yang sejenis sehingga selisih sedikit saja harga dari toko yang lain } \\
\text { kadang pelanggan juga suka, misalkan selisih } 500 \text { rupiah atau } 1000 \text { rupiah yang } \\
\text { penting bagaimana cara kita memberikan harga yang sangat terjangkau bagi } \\
\text { masyarakat dan barang yang kompetitif, seperti itu". }\end{array}$ \\
\hline 4 & $\begin{array}{l}\text { Apa yang menjadi pembeda atau kelebihan yang dimiliki oleh TB. Purnama } \\
\text { dibandingkan dengan pesaing yang lain? } \\
\text { Jawaban: "Kita bisa memberikan harga yang lebih terjangkau dengan barang } \\
\text { berkualitas sebaik mungkin dan memberikan pelayanan yang ramah, cepat, dan } \\
\text { kirimian secepat dan semaksimal mungkin kita bisa, paling itu". }\end{array}$ \\
\hline 5 & $\begin{array}{l}\text { Untuk promosi TB. Purnama sendiri jenis media yang digunakan apa saja? } \\
\text { Jawaban: "Sementara untuk promosi itu masih seperti toko biasa ya dari mulut ke } \\
\text { mulut dan kadang dari tukang ke pelanggan, tukang mempunyai konsumen yang ingin } \\
\text { membuat rumah menginformasikan ke toko kami, dan sekarang mungkin dari } \\
\text { whatsapp dan status whatsapp, sementara itu saja". }\end{array}$ \\
\hline 6 & $\begin{array}{l}\text { Bagaimana cara menjaga hubungan dengan stakeholder (pelanggan, karyawan, dan } \\
\text { supplier)? } \\
\text { Jawaban: "Untuk supplier pertama untuk menjaga, kita harus menjaga kepercayaan } \\
\text { dengan membayar tagihan nota itu secara tepat waktu sesuai jatuh tempo atau } \\
\text { sebelum jatuh tempo dari nota itu sendiri dan kita sebisa mungkin menjaga } \\
\text { kepercayaan dari distributor. Untuk pelanggan sendiri kita dengan cara tidak } \\
\text { mengecewakan pelanggan dengan pelayanan yang baik, ramah, dan pengiriman } \\
\text { secepat yang kita bisa dan memberikan harga yang kompetitif dan terjangkau seperti } \\
\text { yang poin sebelumnya. Untuk karyawan kita memberikan hari libur pasti, kita } \\
\text { memberikan kadang kalua kiriman sampai melebihi jam kerja kita ada tambahan uang } \\
\text { istilahnya uang lemburan dan kadang kita memberikan pelayanan kesehatan bagi } \\
\text { karyawan dan keluarga karyawan, seperti itu". }\end{array}$ \\
\hline
\end{tabular}

Kartika, et al,. [Pengembangan Sistem Penjualan Menggunakan UML dan Proses Bisnis E-Commerce pada TB. Purnama Banjarnegara] 


\begin{tabular}{|c|l|}
\hline 7 & $\begin{array}{l}\text { Apa kendala yang dihadapi pada model bisnis yang ada saat ini? } \\
\text { Jawaban: "Kendalanya sementara proses pemasaran yang kurang luas karena } \\
\text { memang media untuk penjualan masih terbatas di lingkungan sekitar ataupun dalam } \\
\text { jangkauan kecamatan belum bisa jangkauan luar kecamatan ataupun kabupaten dan } \\
\text { kendala dalam pengoperasian stok barang seperti manajemen barang masuk barang } \\
\text { keluar karena masih menggunakan manual". }\end{array}$ \\
\hline 8 & $\begin{array}{l}\text { Apakah TB. Purnama sudah menerapkan penjualan secara online? } \\
\text { Jawaban: "Sementara belum". }\end{array}$ \\
\hline 9 & $\begin{array}{l}\text { Apakah TB. Purnama sudah memiliki website sendiri? } \\
\text { Jawaban: "Sementara juga belum, kita masih menggunakan cara manual". }\end{array}$ \\
\hline 10 & $\begin{array}{l}\text { Bagaimana pendapat bapak mengenai penjualan secara online? } \\
\text { Jawaban: "Oh bagus sekali, ya itu bisa memperluas jangkauan pemasaran dan } \\
\text { memperkenalkan produk kita yang bisa dijangkau oleh banyak pelanggan khususnya di } \\
\text { luar daerah saya untuk mengembangkan bisnis dari tempat saya". }\end{array}$ \\
\hline $\begin{array}{l}\text { Menurut bapak bagaimana peluang usaha toko bangunan saat ini? } \\
\text { Jawaban: "Untuk peluang usaha sementara untuk toko bangunan sendiri sepertinya } \\
\text { sudah banyak pesaing karena dalam satu desa atau satu wilayah saja bisa sampai ada } \\
\text { 2 atau } 3 \text { toko yang sama dan sejenis, mungkin kedepannya untuk pengembangannya } \\
\text { kita harus lebih lengkap, lebih murah, dan pelayanan lebih bagus, ataupun untuk } \\
\text { pengembangan bisnis yang lain mungkin kita harus menjangkau bisnis yang berbeda } \\
\text { dari toko bangunan lain, karena toko bangunan khususnya di daerah sini sudah } \\
\text { banyak sekali toko-toko sejenis". }\end{array}$ \\
\hline
\end{tabular}

Hasil observasi dan dokumentasi penelitian ini disajikan pada Gambar 2 dan Gambar 3. Gambar 2 merupakan dokumentasi proses pelayanan di TB.Purnama, dan Gambar 3 merupakan dokumentasi proses pembuatan nota belanja di TB.Purnama.

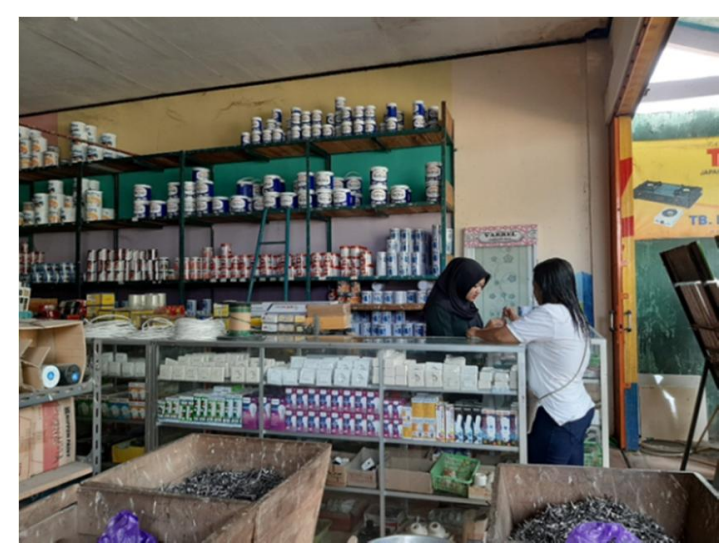

Gambar 2. Proses Pelayanan di TB. Purnama

Kartika, et al,. [Pengembangan Sistem Penjualan Menggunakan UML dan Proses Bisnis E-Commerce pada TB. Purnama Banjarnegara] 


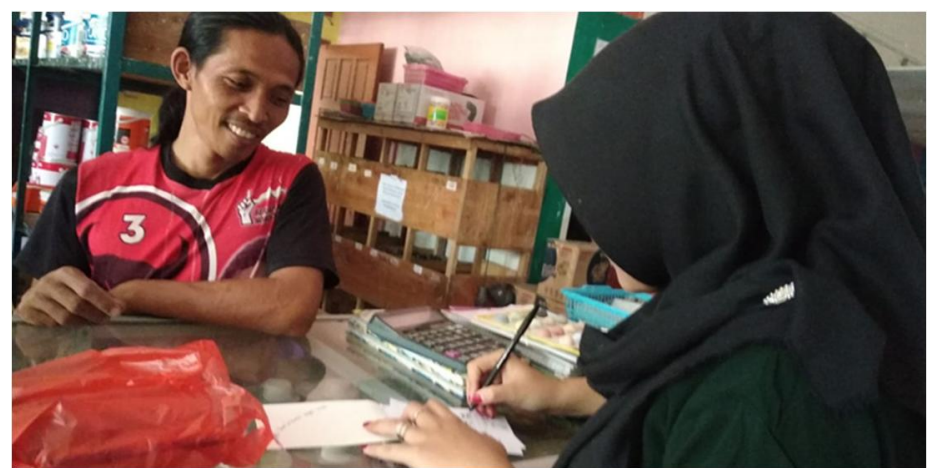

Gambar 3. Proses Pembuatan Nota Belanja di TB. Purnama

\subsection{Identifikasi Model Bisnis Berjalan}

Berdasarkan data yang telah diperoleh dari proses wawancara, observasi, dan dokumentasi, menunjukkan bahwa model bisnis dan sistem penjualan di TB.Purnama masih dilakukan dengan cara manual, dimana konsumen datang langsung ke toko untuk mencari dan membeli produk yang diinginkan. Pada model bisnis yang sedang berjalan ini, disajikan menggunakan activity diagram, yang aktornya terdiri dari: konsumen, pelayan, kasir, karyawan bongkar muat, dan sopir. Silakan dicermati Gambar 4.

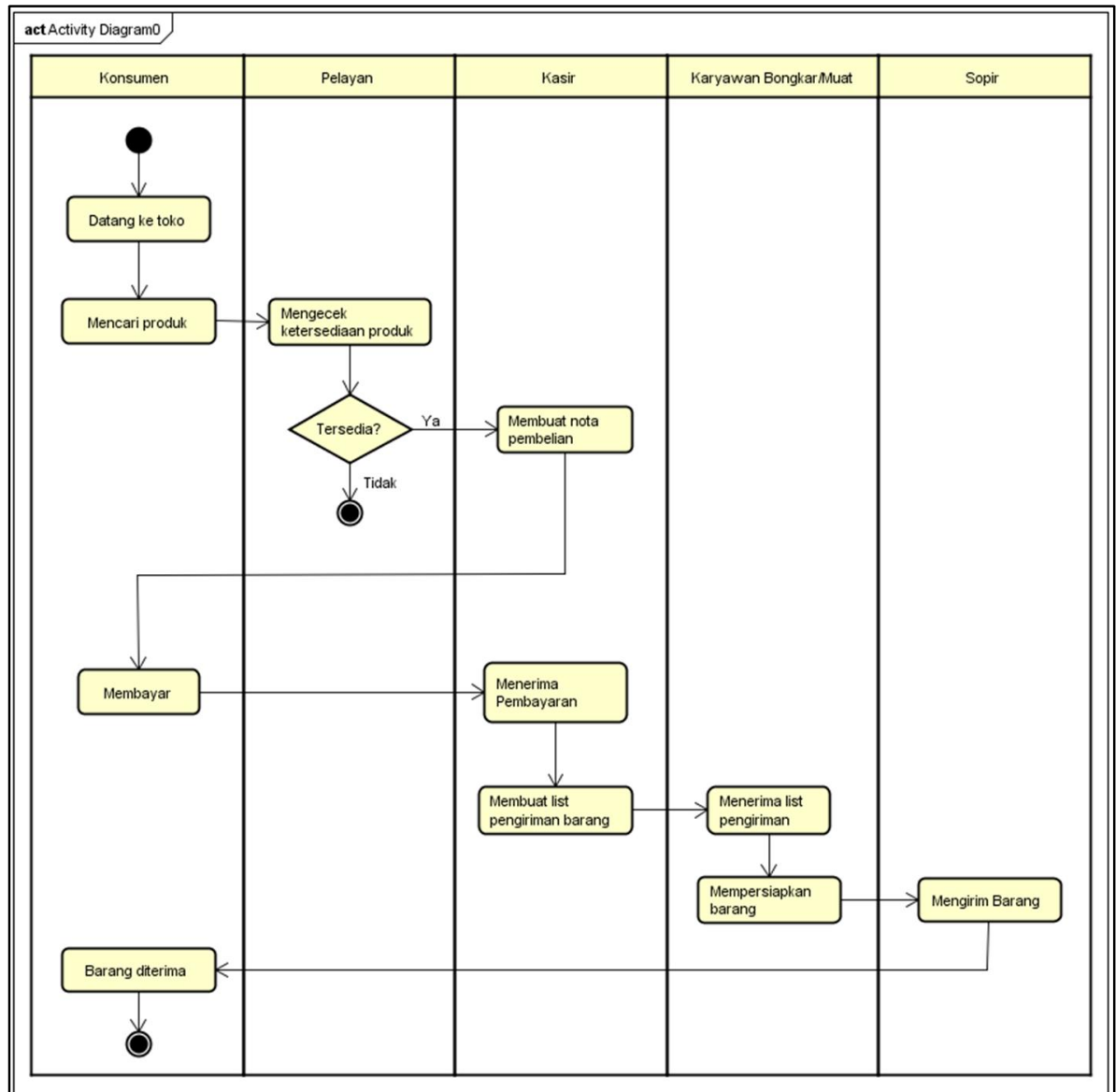

Gambar 4. Activity Diagram Model Bisnis Berjalan

Kartika, et al,. [Pengembangan Sistem Penjualan Menggunakan UML dan Proses Bisnis E-Commerce pada TB. Purnama Banjarnegara] 
Merujuk pada Gambar 4, berikut ini merupakan penjelasan model bisnis berjalan yang ada di TB. Purnama. Konsumen mendatangi toko bangunan, selanjutnya konsumen mencari produk yang diinginkan dengan cara menanyakan kepada pelayan toko. Pelayan mengecek ketersediaan produk yang dicari oleh konsumen. Jika produk tersedia, kemudian kasir membuatkan nota pembelian. Setelah itu, konsumen membayar sesuai dengan harga barang yang dibeli. Kasir menerima pembayaran dan memeberika barang yang dibeli kepada konsumen. Jika barang perlu menggunakan jasa pengiriman, maka kasir akan membuat list pengiriman barang yang kemudian diserahkan kepada karyawan bongkar muat. Karyawan bongkar muat menyiapkan barang yang akan dikirimkan. Sopir mengirimkan barang ke tempat konsumen. Barang diterima oleh konsumen.

\subsection{Evaluasi Model Bisnis Berjalan Melalui SWOT}

SWOT merupakan teknik analisis yang digunakan untuk mengidentifikasi berbagai faktor secara sistematis untuk merumuskan strategi perusahaan yang didasarkan pada logika yang dapat memaksimalkan kekuatan (Strengths) dan peluang (Opportunities), namun secara bersamaan dapat meminimalkan kelemahan (Weakness) dan ancaman (Threats) [19]. Berikut ini merupakan pemetaan matrik SWOT, yang diperoleh berdasarkan hasil wawancara dan observasi pada TB. Purnama Banjarnegara yang disajikan pada Gambar 5.

\begin{tabular}{|c|c|}
\hline \multicolumn{2}{|c|}{ SWOT Analysis } \\
\hline \begin{tabular}{ll} 
& \multicolumn{1}{c}{ Strengths } \\
- & Pembagian tugas karyawan jelas \\
- & Harga produk \\
- & Produk yang dijual beragam \\
- $\quad$ Bentuk pelayanan \\
- $\quad$ Selalu menjaga hubungan baik \\
$\quad$ dengan stakeholder
\end{tabular} & $\begin{array}{l}\text { Weakness } \\
\text { - Manajemen stok barang } \\
\text { - Jangkauan pemasaran } \\
\text { - Media promosi } \\
\text { - Proses penjualan } \\
\quad \text { (konvensional) }\end{array}$ \\
\hline $\begin{array}{l}\text { Opportunities } \\
\text { - Penggunaan platfrom teknologi } \\
\text { informasi untuk membantu } \\
\text { meningkatkan penjualan dan } \\
\text { memperluas jangkauan } \\
\text { pemasaran }\end{array}$ & $\begin{array}{l}\text { Threats } \\
\text { - Kompetitor }\end{array}$ \\
\hline
\end{tabular}

Gambar 5. Matriks Model Bisnis Berjalan SWOT TB. Purnama

Merujuk Gambar 5, strengths yang dimiliki TB. Purnama, yaitu: pembagian tugas karyawan jelas, harga produk terjangkau, produk yang dijual beragam, pelayanan yang ramah, selalu menjaga hubungan baik dengan stakeholder. Weakness yang dimiliki, yaitu: manajemen stok barang yang kurang diperhatikan, jangkauan pemasaran terbatas, media promosi terbatas, dan proses penjualan (konvensional). Opportunities yang dimiliki, yaitu: penggunaan platform teknologi informasi dalam dunia bisnis. Threats yang dihadapi adalah persaingan antar kompetitor.

\subsection{Rancangan UML Rekomendasi Perbaikan Model Bisnis}

Berdasarkan hasil analisis SWOT yang telah dilakukan sebelumnya, untuk mengatasi kelemahan dan tantangan yang dihadapi oleh TB. Purnama, maka dibuatlah sebuah rancangan perbaikan model bisnis berupa sistem penjualan e-commerce TB. Purnama berbasis web, yaitu:

Kartika, et al,. [Pengembangan Sistem Penjualan Menggunakan UML dan Proses Bisnis E-Commerce pada TB. Purnama Banjarnegara] 
1. Use Case Diagram

Use case diagram merupakan diagram yang digunakan untuk menggambarkan interaksi pengguna dengan sistem [16]. Use case diagram rekomendasi TB. Purnama terdiri dari dua aktor, yaitu konsumen dan administrator. Selain itu, use case diagram ini memiliki interaksi pada 12 use case, yaitu: login, register, cari produk, beli produk, checkout, konfirmasi pembayaran, input produk, update produk, hapus produk, verifikasi pembayaran, mengelola pesanan, dan rekap data penjualan. Berikut ini, merupakan use case diagram rekomendasi TB. Purnama.

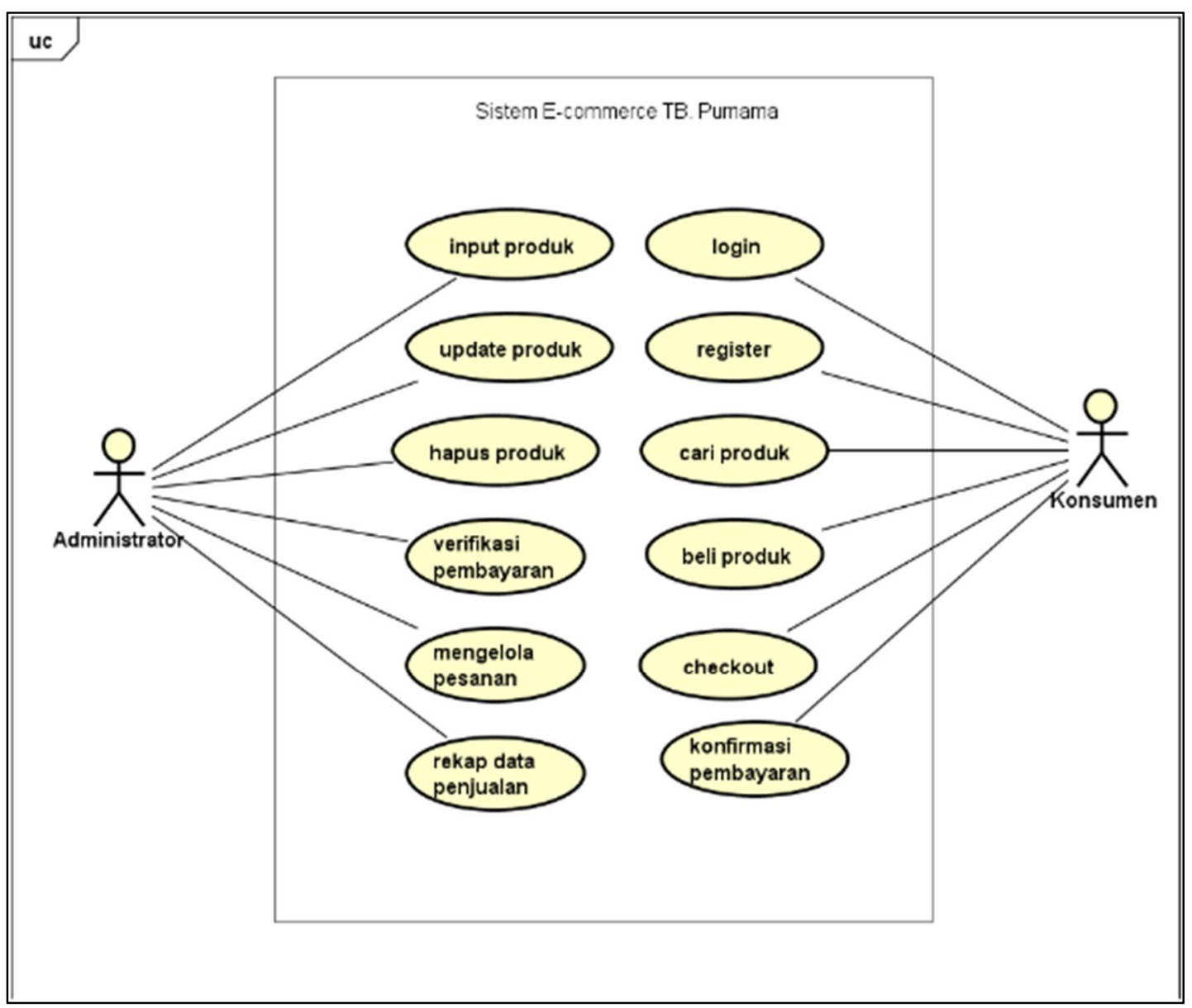

Gambar 6. Use Case Diagram Model Bisnis Rekomendasi

2. Use Case Scenario

Use case scenario merupakan rincian gambaran dari sebuah kegiatan atau use case, dan setiap use case memiliki satu use case scenario. Setiap use case dalam use case diagram, harus memiliki use case scenario yang menjelaskan setiap langkah pada use case terkait [11], [9]. Dari 12 use case scenario yang digunakan dalam penelitian, berikut ini hanya disajikan salah satu contoh use case scenario saja, bernama Use Case Scenario Verifikasi Pembayaran. 


\begin{tabular}{|l|l|}
\hline Use case name: & Verifikasi pembayaran \\
\hline Actor: & Administrator \\
\hline Description: & $\begin{array}{l}\text { Administrator melakukan verifikasi pembayaran } \\
\text { pesanan milik konsumen }\end{array}$ \\
\hline
\end{tabular}

Step performed:

1. Administrator memilih menu Uploaded Files

2. Sistem menampilkan semua file bukti pembayaran yang berhasil di upload ke sistem

3. Administrator mengunduh file bukti pembayaran pada database website

4. Sistem memberikan file bukti pembayaran

5. Administrator menyimpan bukti pembayaran

6. Administrator memeriksa bukti pembayaran

7. Jika jumlah pembayaran sesuai, barang akan dikirimkan kepada konsumen

8. Jika tidak sesuai, Administrator akan melakukan konfirmasi ulang kepada konsumen terkait pembayaran

9. Konsumen mengirimkan ulang bukti pembayaran yang sudah sesuai

10. Barang dikirimkan kepada Konsumen

\begin{tabular}{|l|l|}
\hline Preconditions: & $\begin{array}{l}\text { Administrator ingin melakukan verifikasi pembayaran } \\
\text { pesanan konsumen }\end{array}$ \\
\hline Postconditions: & $\begin{array}{l}\text { Administrator telah menyelesaikan proses verifikasi } \\
\text { pembayaran }\end{array}$ \\
\hline
\end{tabular}

Gambar 7. Use Case Scenario Verifikasi Pembayaran

Merujuk pada Gambar 7, maka pada pembahasan ini, melibatkan aktor bernama Administrator yang berperan sebagai pengelola sistem. Dalam melalukan kegiatannya, aktor ini memiliki 10 langkah urutan kegiatan yang dilakukan dalam melakukan verifikasi pembayaran. Langkah pertama yang dilakukan, yaitu Administrator memilih menu Upload Files yang ada pada. Setelah itu, sistem akan menampilkan semua daftar file bukti pembayaran yang berhasil di upload ke dalam database sistem. Langkah selanjutnya, Administrator mengunduh file bukti pembayaran, kemudian sistem akan memberikan file bukti pembayaran. Administrator menyimpan bukti pembayaran sekaligus memeriksa bukti tersebut. Jika jumlah pembayaran sesuai, barang akan dikirimkan kepada konsumen. Jika tidak, Administrator akan melakukan konfirmasi ulang kepada konsumen. Konsumen mengirimkan ulang bukti pembayaran yang sudah sesuai, dan langkah terakhir yaitu barang dikirimkan kepada konsumen.

3. Activity Diagram

Activity diagram menunjukkan urutan kegiatan pada suatu proses, termasuk kegiatan yang sifatnya berurutan atau paralel [16] Setiap urutan kegiatan pada suatu activity diagram merupakan gambaran dari deskripsi use case scenario, sehingga setiap activity diagram, harus memiliki use case scenario [11], [9]. Setiap activity diagram menggambarkan satu use case. Berikut ini merupakan activity diagram rekomendasi perbaikan model bisnis TB.Purnama. Dari 12 activity diagram yang digunakan dalam penelitian, berikut ini hanya disajikan salah satu contoh activity diagram saja, bernama Verifikasi Pembayaran.

Kartika, et al,. [Pengembangan Sistem Penjualan Menggunakan UML dan Proses Bisnis E-Commerce pada 


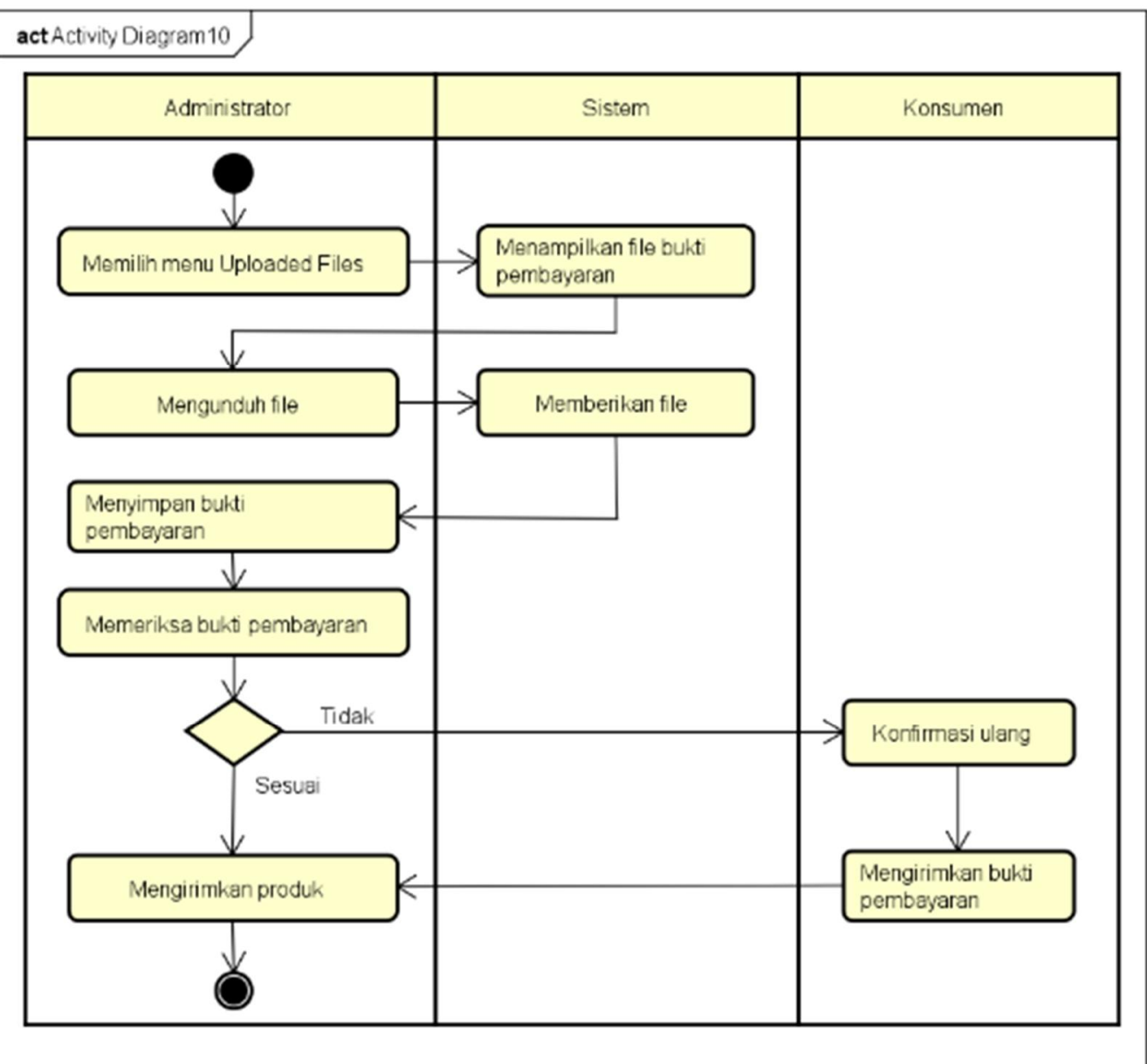

Gambar 8. Activity Diagram Verifikasi Pembayaran

Merujuk pada Gambar 8, langkah pertama verifikasi pembayaran dimulai pada aktor Administrator memilih menu Upload Files, kemudian sistem merespon permintaan Administrator dengan menampilkan file bukti pembayaran. Setelah list file bukti pembayaran muncul, Administrator mengunduh file yang telah di upload, kemudian sistem merespon dengan memberikan file yang ada dalam database sistem. Setelah itu, Administrator menyimpan bukti pembayaran dan memeriksa bukti pembayaran tersebut. Apabila pembayaran sesuai, maka barang akan langsung dikirimkan kepada konsumen. Jika tidak, Administrator akan melakukan konfirmasi ulang kepada Konsumen. Konsumen kemudian mengirimkan Kembali bukti pembayaran yang sudah sesuai dan barang akan langsung dikirimkan.

4. Sequence Diagram

Sequence diagram merupakan diagram yang digunakan untuk menggambarkan pemrosesan yang ada dalam use case scenario. Dalam praktiknya, sequence diagram sering digunakan dalam proses desain sistem untuk memperoleh interaksi, hubungan, dan berbagai metode objek-objek dalam sistem [16]. Setiap satu sequence diagram yang dibuat dalam rangkaian UML, harus merujuk pada satu activity diagram [11], [9]. Dari 12 sequence diagram yang digunakan dalam penelitian, berikut ini hanya disajikan salah satu contoh sequence diagram saja, bernama Verifikasi Pembayaran yang disajikan pada Gambar 9. 


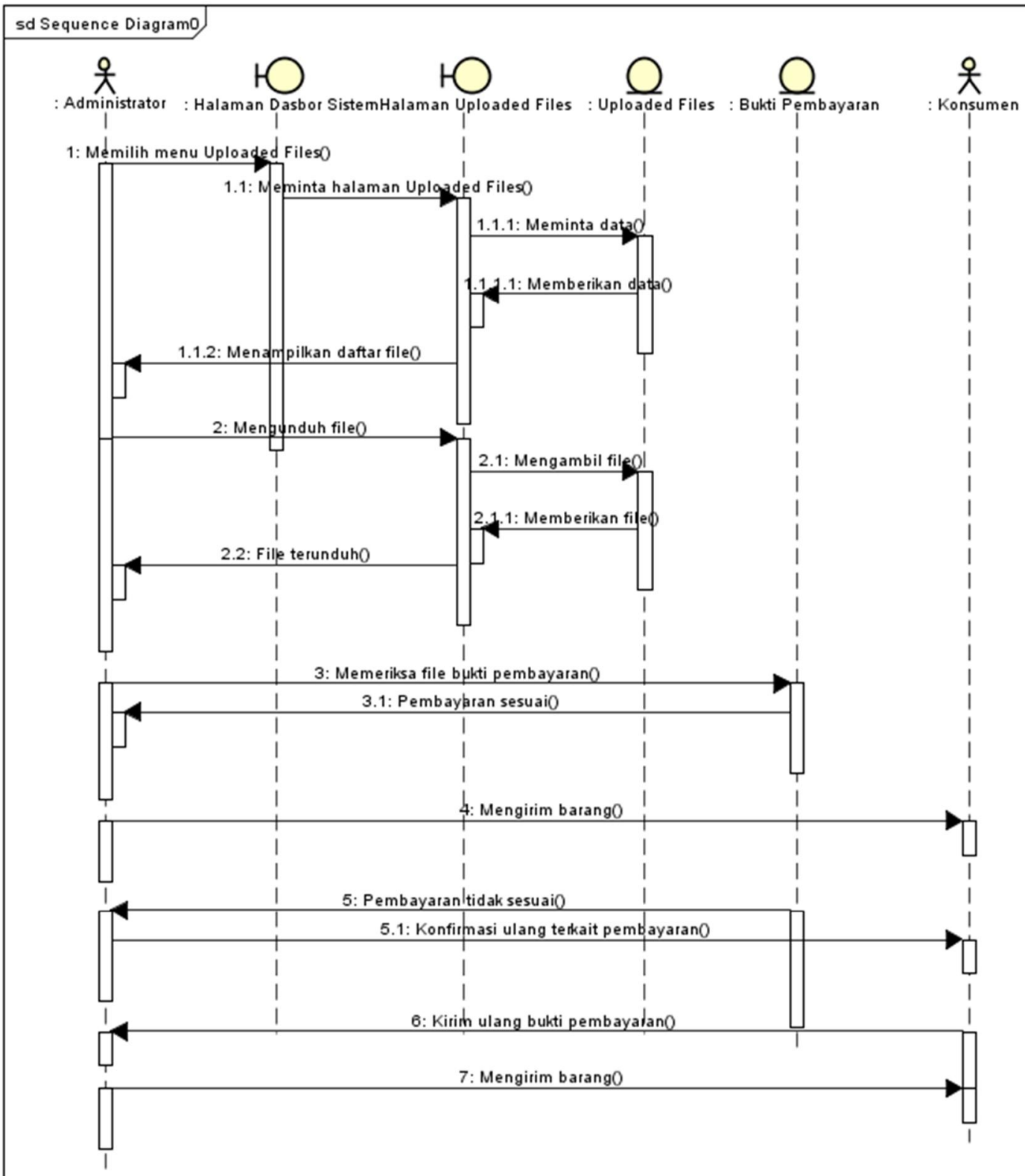

Gambar 9. Sequence Diagram Verifikasi Pembayaran

Sequence Diagram pada Gambar 9, merupakan pemrosesan dari use case scenario yang telah disajikan sebelumnya pada Gambar 7. Langkah pertama, yaitu Administrator memilih menu Upload Files pada Halaman Dasbor Sistem. Sistem kemudian meminta hak akses data-data yang telah di-upload kepada Database Upload Files. Setelah mendapatkan akses, file-file yang telah diuplaod akan ditampilkan pada Halaman Upload Files. Kemudian Administrator mengunduh file yang sudah ditampilkan. Sistem akan meminta hak akses untuk mengunduh file pada database, dengan cara memberikan hak akses, lalu file disimpan oleh Administrator. Langkah selanjutnya, yaitu Administrator memeriksa bukti pembayaran. Apabaila pembayaran sesuai, maka barang akan langsung dikirimkan kepada konsumen. Jika tidak, Administrator akan melakukan konfirmasi ulang kepada

Kartika, et al,. [Pengembangan Sistem Penjualan Menggunakan UML dan Proses Bisnis E-Commerce pada 
Konsumen. Konsumen kemudian mengirimkan kembali bukti pembayaran yang sudah sesuai dan barang akan langsung dikirimkan.

5. Class Diagram

Class diagram merupakan diagram statis yang digunakan untuk memodelkan tampilan statis sistem dan tidak mewakili pemrosesan tertentu [16].

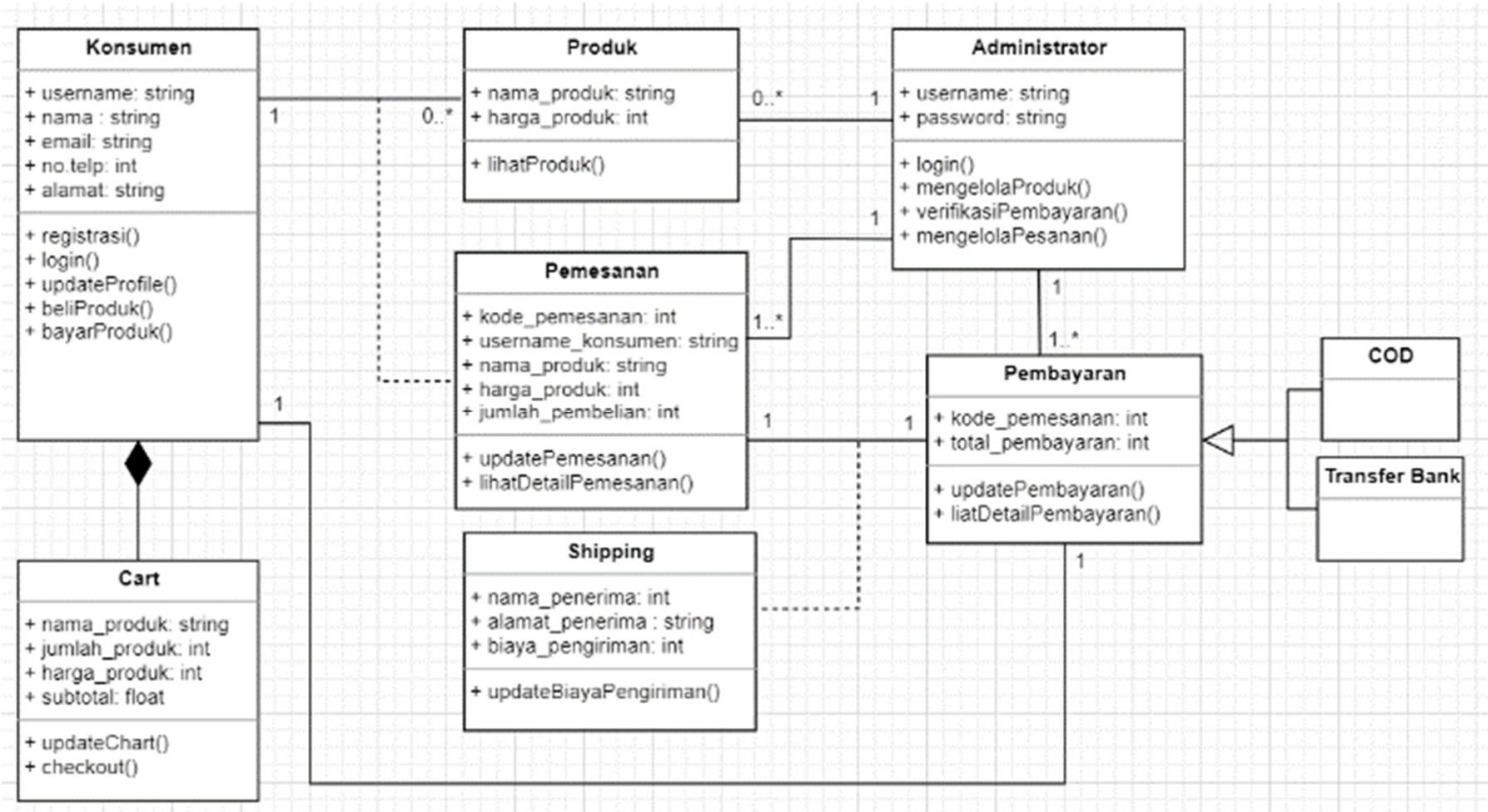

Gambar 10. Class Diagram Model Bisnis Berjalan

Berdasarkan Gambar 10, terdapat tujuh kelas yang saling terhubung pada model bisnis rekomendasi TB.Purnama, yaitu: Konsumen, Produk, Administrator, Pemesanan, Pembayaran, Shipping, dan Cart. Pada kelas Pembayaran terdapat dua jenis pembayaran yang dapat dilakukan, yaitu melalui cash on delivery (COD) dan transfer bank.

\subsection{Prototype User Interface Website}

Pembuatan prototype user interface website e-commerce, sebagai model bisnis rekomendasi penelitian ini dirancang menggunakan Content Management System (CMS) Wordpress. Prototype untuk user interface yang disajikan pada contoh desain ini, merupakan dua contoh untuk tampilan halaman Shop dan halaman konfirmasi pembayaran, sebagai berikut: 
a. Tampilan Hamaman Shop

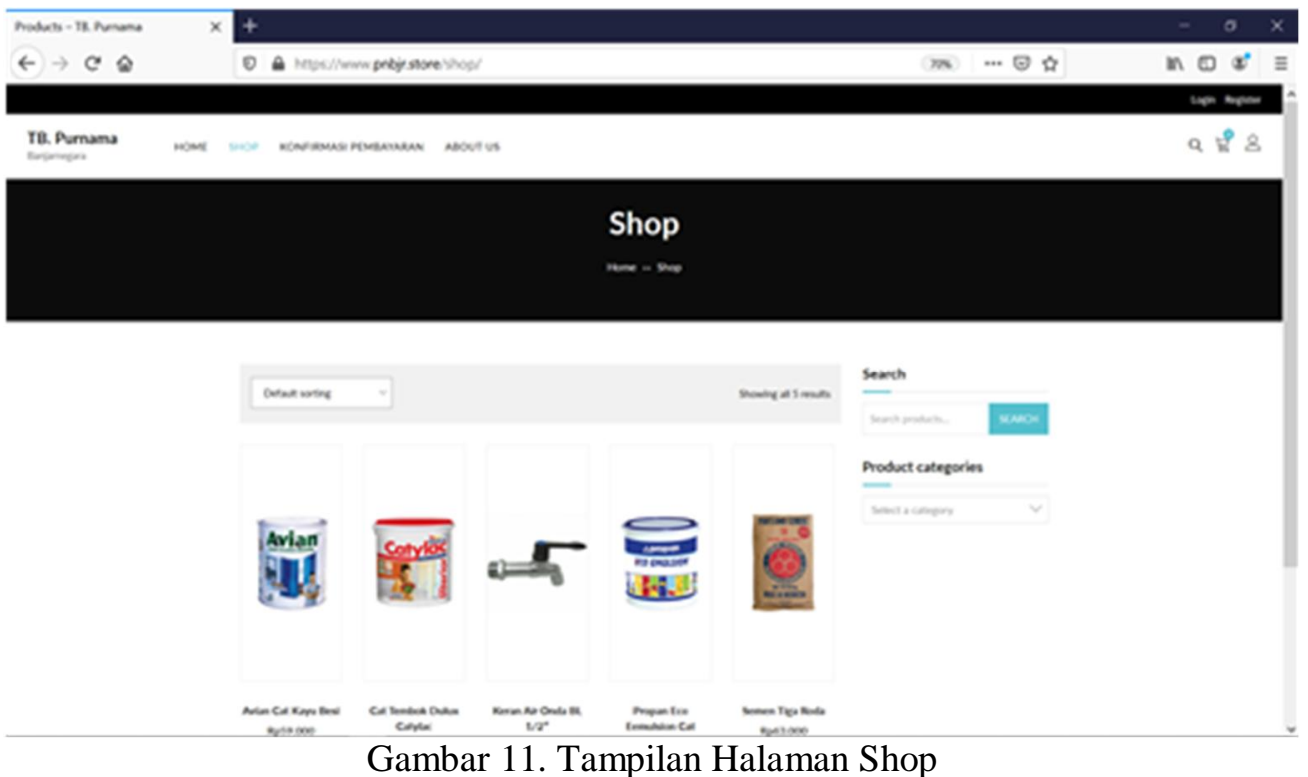

Merujuk Gambar 11, merupakan contoh tampilan produk-produk yang ditawarkan pada e-comerce TB. Purnama. Pada halaman Shop ini terdapat berbagai jenis pilihan produk bahan bangunan yang dijual, seperti: cat, semen, keran, dan lain-lain. Pada halaman ini terdapat fitur sorting, yang dapat digunakan oleh pengunjung untuk menentukan urutan bagaimana produk akan ditampilkan. Pilihan sorting yang tersedia, yaitu: sort by popularity, sort by average rating, sory by latest, sort by price: low to high, dan sort by price: high to low. Selain itu, pada halaman Shop juga terdapat widget Search dan Product Categories, yang dapat membantu konsumen untuk mencari barang yang diinginkan saja, tanpa harus menampilkan semuanya.

b. Tampilan Halam Konfirmasi Pembayaran

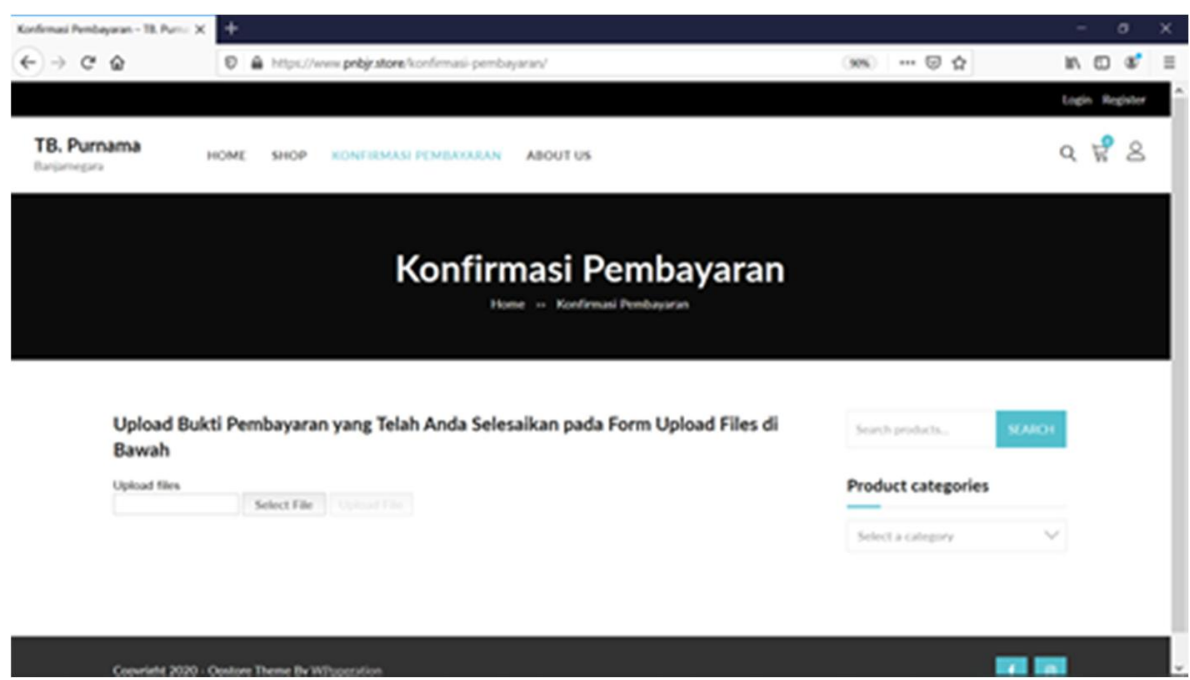

Gambar 12. Tampilan Halaman Konfirmasi Pembayaran

Kartika, et al,. [Pengembangan Sistem Penjualan Menggunakan UML dan Proses Bisnis E-Commerce pada TB. Purnama Banjarnegara] 
Merujuk Gambar 12, merupakan contoh tampilan saat terjadi transaksi untuk konfirmasi pembayaran pada e-comerce TB Purnama. Pada halaman konfirmasi pembayaran ini, terdapat fitur Upload Files yang digunakan untuk mengunggah file bukti pembayaran atas transaksi yang telah dilakukan sebelumnya. Untuk menggunakan fitur tersebut, pengunjung dapat memilih menu Select File kemudian browser akan meminta file mana yang akan di-upload dari perangkat pengguna. Setelah file terpilih, pengunjung memilih tombol Upload File untuk mengirimkan file tersebut.

\subsection{Uji Validitas dan Reliabilitas}

Setelah dilakukan analisis terhadap model bisnis yang sedang terjadi di TB. Purnama, dan pemberian rekomendasi perbaikan model bisnis, maka langkah selanjutnya adalah melakukan uji validitas dan reliabilitas, terhadap hasil rekomendasi model bisnis dan tampilan prototype user interface website e-commerce TB. Purnama. Alat yang digunakan untuk melakukan proses pengujian tersebut yaitu Gwet's AC1. Proses perhitungan, dilakukan setelah melalui suatu daftar pertanyaan, berupa kuesioner mengenai model bisnis rekomendasi dan tampilan user interface website kepada dua orang pakar. Pakar pertama, berprofesi sebagai Staff Pengajar Analisis dan Perancangan Sistem. Untuk pakar yang kedua, berprofesi sebagai pemilik dari TB. Purnama. Kedua pakar tersebut, dijadikan sebagai narasumber yang penting dalam melakukan pengujian hasil penelitian ini. Terdapat 31 butir pertanyaan yang diajukan kepada para pakar, mengenai rekomendasi model bisnis, dan tampilan prototype user interface website ecommerce. Berikut ini, merupakan hasil perhitungan uji validitas dan reliabilitas menggunakan Gwet's AC1. Lihat Tabel 4.

Tabel 4. Hasil Pertanyaan Kuesioner Pengamat

\begin{tabular}{|c|c|c|c|}
\hline \multirow{2}{*}{ Pengamat 1 } & \multicolumn{3}{|c|}{ Pengamat 2 } \\
\cline { 2 - 4 } & Ya & Tidak & Total \\
\hline Ya & 25 & 0 & 25 \\
\hline Tidak & 4 & 2 & 6 \\
\hline Total & 29 & 2 & 31 \\
\hline
\end{tabular}

Langkah perhitungan pertama yang dilakukan, yaitu menghitung kesepakatan terobservasi $(\mathrm{P})$ antar kedua pakar yang sebelumnya telah disajikan pada persamaan (1).

$$
\mathrm{P}=\frac{25+2}{31}=0.87097
$$

Langkah selanjutnya, yaitu menghitung probabilitas chance-agreement atau $\mathrm{e}(\mathrm{\gamma})$ yang sebelumnya terdapat pada rumus (2).

$$
\begin{gathered}
\mathrm{P}_{1}=\frac{25+0 / 2}{31}=0.40323 \\
e(\mathrm{\gamma})=2(0.40323)(1-0.40323)=0.75125
\end{gathered}
$$

Setelah didapatkan hasil perhitungan dari Kesepakatan Terobservasi (P) dan Probabilitas Chance-Agreement $(\mathrm{e}(\mathrm{\gamma})$ ), maka selanjutnya dapat dilakukan perhitungan nilai Statistika AC1, yang rumusnya sudah tersaji pada rumus (3) di atas. Berikut ini merupakan hasil perhitungannya.

$$
\mathrm{ACl}=\frac{0.87097-0.48127}{1-0.48127}=0.75125
$$


Berdasarkan hasil perhitungan di atas, didapatkan nilai kesepakatan dari kedua pakar, yaitu sebesar 0,75125. Nilai Statistika AC1 atau nilai index kappa yang telah diperoleh tersebut dapat diinterpretasikan ke dalam jenis proporsi kesepakatan "Substansial". Hal tersebut dapat dilihat pada Tabel I. Proporsi kesepakatan yang dihasilkan dari kedua pakar menunjukkan bahwa rekomendasi perbaikan model bisnis serta prototype user interface website sudah baik, dan model bisnis rekomendasi dapat diterapkan pada kegiatan bisnis TB.Purnama. Penerapan model bisnis rekomendasi tersebut diharapkan mampu membantu TB.Purnama dalam mengatasi kelemahan yang ada pada model bisnis berjalan, dan juga membantu dalam menghadapi persaingan bisnis dengan para kompetitornya.

\section{KESIMPULAN}

Berdasarkan penelitian yang telah dilakukan, untuk mengatasi kelemahan yang ada pada TB.Purnama, dibuatlah sebuah rekomendasi perbaikan model bisnis berjalan TB. Purnama, berupa sistem penjualan e-commerce bahan bangunan berbasis web. Pemberian perbaikan model bisnis rekomendasi ini, dilakukan tanpa menghilangkan model bisnis konvensional yang sudah ada. Dalam merepresentasikan model bisnisnya, sistem ini menggunakan pemodelan UML. Proses perancangan untuk prototype sistem penjualan telah berhasil dibuat, melalui adopsi proses bisnis yang terdapat pada proses e-commerce dan pembuatan user interface web. Hasil dari UML pada penelitian ini, adalah Use Case Diagram Sistem E-Commerce TB.Purnama, yang terdiri dari Use Case Scenario, Activity Diagram, dan Sequence Diagram dengan jumlah sama, yaitu 12 diagram yang bernama: Login, Register, Cari Produk, Beli Produk, Checkout, Konfirmasi Pembayaran, Input Produk, Update Produk, Hapus Produk, Verifikasi Pembayaran, Mengelola Pesanan, dan Rekap Data Penjualan. Selain itu, UML ini juga menghasilkan suatu Class Diagram bernama Class Diagram Sistem E-Commerce TB. Purnama yang terdiri dari 7 Class, yaitu: Konsumen, Produk, Administrator, Pemesanan, Pembayaran, Shipping, dan Cart. Hasil uji validitas dan reliabilitas terhadap rekomendasi perbaikan model bisnis dan prototype user interface website, menggunakan perhitungan statistika Gwet's AC1 menghasilkan nilai sebesar 0,75125. Nilai Statistika AC1 atau nilai index kappa yang telah diperoleh tersebut, dapat diinterpretasikan ke dalam jenis proporsi kesepakatan jenis "Substansial". Proporsi kesepakatan dari hasil validitas dan reliabilitas yang dihasilkan dari kedua pakar menunjukan, bahwa rekomendasi perbaikan model bisnis serta prototype user interface website sudah baik dan model bisnis rekomendasi dapat diterapkan pada kegiatan bisnis TB. Purnama.

\section{SARAN}

Keterbatasan sistem yang dirancang pada penelitian ini, berfokus pada proses penjualan saja, sehingga saran untuk penelitian selanjutnya agar menjadi lebih berkembang cakupannya adalah melakukan kolaborasi pada media sosial sebagai platform untuk membantu proses promosi produk. 


\section{DAFTAR PUSTAKA}

[1] K. C. Laudon and C. G. Traver, 2017, E-commerce, Pearson, Boston.

[2] M. Yulia and Y. Priyadi, 2019, "Pengembangan Model E-Commerce Melalui Rekayasa Proses Bisnis Untuk Penggunaan Modul Voucher pada Website Rubylicious," Sosio Humanitas, Vol. XXI, No. 2, pp. 116-125.

[3] Y. A. Nanehkaran, 2013, "Introduction to Electronic Commerce," Int. J. Sci. Technol. Reserach, Vol. II, No. 4, pp. 69-87, doi: 10.1007/978-1-4471-3018-5_6.

[4] N. Anwary, A. Deddy, and R. Kurniawati, 2014, "Hardcore Menggunakan Metode Berorientasi Objek,” J. Algoritm., Vol. XI, No. 1, pp. 1-9.

[5] S. Handayani, 2018, "Perancangan Sistem Informasi Penjualan Berbasis E-Commerce Studi Kasus Toko Kun Jakarta," Ilk. J. Ilm., Vol. X, No. 2, pp. 182-189, doi: 10.33096/ilkom.v10i2.310.182-189.

[6] J. Ernawati, "Industri Bahan Bangunan Makin Bergairah," Viva.co.id, 2017. https://www.viva.co.id/berita/bisnis/916454-industri-bahan-bangunan-makin-bergairah (accessed Jun. 20, 2020).

[7] A. Nararya, Hermansyah, and Y. Kusdiantono, 2018. "Bisnis Digital Dituntut Perluas Pasar,” Sindonews, https://ekbis.sindonews.com/berita/1271619/34/bisnis-digitaldituntut-perluas-pasar (accessed Jun. 20, 2020).

[8] J. Zheng, Y. Feng, and Y. Zhao, 2014, "A Unified Modeling Language-Based Design and Application for A Library Management Information System," Cybern. Inf. Technol., Vol. XIV, No. SpecialIssue, pp. 129-144, doi: 10.2478/cait-2014-0050.

[9] R. Rundupadang and Y. Priyadi, 2018, "Perancangan UML Sebagai Rekomendasi Proses Bisnis Berdasarkan BMC Di Geoff Max Bandung," J. Wacana Ekon., Vol. XVIII, No. 1, pp. 13-21, [Online]. Available: www.jurnal-uniga.ac.id.

[10] A. Kaur and A. Rajeev, 2012, "Application of UML In Real-Time Embedded Systems," Int. J. Softw. Eng. Appl., Vol. III, No. 2, pp. 59-70, doi: 10.5121/ijsea.2012.3205.

[11] R. Sukmawati and Y. Priyadi, 2019, "Perancangan Proses Bisnis Menggunakan UML Berdasarkan Fit/Gap Analysis pada Modul Inventory Odoo," INTENSIF J. Ilm. Penelit. dan Penerapan Teknol. Sist. Inf., Vol. III, No. 2, pp. 104-115, doi: 10.29407/intensif.v3i2.12697.

[12] M. L. V. R. Vani, M. C. Kumari, M. H. Priya, and N. Harika, 2015, "An Effective Language for Object Oriented Design-UML (Unified Modeling Language)," Int. Resesrch J. Eng. Technol., Vol. II, No. 5, pp. 1212-1218.

[13] Himawan, A. Saefullah, and S. Santoso, 2014, "Analisa dan Perancangan Sistem Informasi Penjualan Online (E-Commerce) pada CV Selaras Batik Menggunakan 
Analisis Deskriptif," Sci. J. Informatics, Vol. I, No. 1, pp. 53-63, doi: 10.15294/sji.v1i1.3641.

[14] R. S. Fitri, K. Rukun, and N. Dwiyani, 2016, "Perancangan dan Implementadi Sistem Informasi Penjualan Komputer dan Accesories pada Toko Mujahidah Computer Berbasis Web," J. Vokasional Tek. Elektron. Inform., Vol. 4, No. 2, pp. 196-211, doi: 10.14800/ics.95.

[15] K. C. Laudon and J. P. Laudon, 2015, Sistem Informasi Manajemen Mengelola Perusahaan Digital, 13th ed, Salemba Empat, Jakarta.

[16] K. E. Kendall and J. E. Kendall, 2014, Systems Analys And Design. Pearson, Ney Jersey.

[17] S. Nurfauziah, D. O. Siahaan, and F. Baskoro, 2017, "Pendeteksian Ketidaklengkapan Kebutuhan Dengan Teknik Klasifikasi pada Dokumen Spesifikasi Kebutuhan Perangkat Lunak," MATICS J. Ilmu Komput. dan Teknol. Inf., Vol. IX, No. 2, pp. 67-71, doi: 10.18860/mat.v9i2.4291.

[18] Y. Priyadi, A. Djunaidy, and D. Siahaan, 2019, "Requirements Dependency Graph Modeling on Software Requirements Specification Using Text Analysis," 2019 1st Int. Conf. Cybern. Intell. Syst. ICORIS 2019, Vol. 1, No. August, pp. 221-226, doi: 10.1109/ICORIS.2019.8874920.

[19] F. Rangkuti, 2016, Analisis SWOT: Teknik Membedah Kasus Bisnis Cara Perhitungan Bobot, Rating, dan OCAI, Gramedia, Jakarta. 